\title{
ANALISIS KINERJA STAKEHOLDER PROGRAM NASIONAL PEMBERDAYAAN MASYARAKAT (PNPM)-MANDIRI KELAUTAN PERIKANAN DI KOTA TERNATE
}

\author{
Nahrawai Djalal ${ }^{1}$, Ridwan Lasabuda ${ }^{2}$
}

\begin{abstract}
To see the success of the PNPM-Mandiri KP in 2009 on the district of Island Hiri, the city of Ternate then performed an analysis of the policy program that analyzes the performance of stakeholders. This study aims to knowing and evaluating the performance of each stakeholder PNPM program - Mandiri KR in Ternate City, namely : head of fisheries, executive consultant, team empowerment, labor and community groups receiving companion program. The research method using survey methods with qualitative descriptive data analysis. Results showed that the performance of the program performance of each head of fisheries $90 \%$; consultant implementing $97 \%$; team empowerment $91 \%$, labour $92 \%$ and the companion community groups $93 \%$..
\end{abstract}

Keywords : analysis of performance, PNPM-Mandiri program

\section{ABSTRAK}

Untuk melihat keberhasilan program PNPM-Mandiri KP Tahun 2009 di Kecamatan Pulau Hiri, Kota Ternate maka dilakukan analisis terhadap kebijakan program tersebut yaitu analisis kinerja stakeholder. Penelitian ini bertujuan untuk mengetahui dan mengevaluasi kinerja masing-masing stakeholder program PNPM-Mandiri KP Kota Ternate, yaitu : Kepala Dinas Perikanan, Konsultan pelaksana, Tim pemberdayaan, Tenaga pendamping dan Kelompok masyarakat penerima program. Metode penelitian menggunakan metode survei dengan analisis data deskriptif kualitatif. Hasil penelitian menunjukan bahwa capaian kinerja pelaksana program masing-masing Kepala Dinas Perikanan 90\%; Konsultan pelaksana 97\%; Tim pemberdayaan $91 \%$; Tenaga pendamping $92 \%$ dan Kelompok Masyarakat 93\%.

Kata kunci : anâlisis kinerja, program PNPM-Mandiri

${ }^{1}$ Mahasiswa Pacasarjana Universitas Sam Ratulangi Manado

${ }^{2}$ Staf pengajar Fakultas Perikanan dan IImu Kelautan Universitas Sam Ratulangi

\section{PENDAHULUAN}

Potensi lestari sumberdaya perikanan laut Indonesia kurang lebih 6,4 juta ton per tahun, terdiri dari : ikan pelagis besar (1,16 juta ton), pelagis kecil (3,6 juta ton), demersal (1,36 juta ton), udang penaeid $(0,094$ juta ton), lobster $(0,004$ juta ton), cumi-cumi $(0,028$ juta ton), dan ikan-ikan karang konsumsi $(0,14$ juta ton). Dari potensi tersebut jumlah tangkapan yang dibolehkan (JTB) sebanyak 5,12 juta ton per tahun, atau sekitar $80 \%$ dari potensi lestari (Numberi, 2009).

Dari potensi sumberdaya perikanan yang melimpah, seharusnya masyarakat pesisir merupakan masyarakat 
yang sejahtera. Kenyataannya hingga kini sebagian masyarakat pesisir, khususnya nelayan masih merupakan masyarakat tertinggal dibandingkan dengan kelompok masyarakat yang lain. Masyzulhak (2005) mengemukakan bahwa hal ini disebabkan karena paradigma pengelolaan sumberdaya perikanan yang tidak tepat sehingga dalam pengendalian input produksi terjadi kesulitan dan tidak berjalan secara optimal.

Fauzi (2005) menjelaskan bahwa hampir sebagai besar nelayan kita masih hidup di bawah garis kemiskinan dengan pendapatan kurang dari US\$ 10/bulan, dan dilihat dari Millenium Development Goals, pendapatan sebesar itu sudah termasuk dalam kategori extreme poverty karena lebih kecil dari 1 US\$ per hari.

Masyarakat pesisir kota Ternate, khususnya yang berada di Kecamatan Hiri, Kota Ternate yang berjumlah 2735 jiwa (BPS Kota Ternate 2011), sebagian besar penduduknya berprofesi sebagai nelayan. Kondisi kehidupan ekonomi mereka masih relatif rendah dan juga kurang tersentuh program-program pemerintah khususnya program pemberdayaan ekonomi masyarakat.

Salah satu program pemerintah untuk pemberdayaan masyarakat adalah Program Nasional Pemberdayaan Masyarakat Mandiri-Kelautan Perikanan (PNPM-Mandiri KP). Di Kecamatan Hiri, kota Ternate program ini telah berjalan sejak tahun 2009, dimana program ini bertujuan untuk meningkatkan kesejahteraan masyarakat pesisir serta memberikan kesempatan berusaha bagi mereka. Harapannya program ini dapat tepat sasaran serta berkelanjutan melalui pemberian bantuan langsung masyarakat (BLM) yang berhak menerimanya.

Pengalaman dari pelaksanaan program pemberdayaan masyarakat pesisir selain program PNPM-Mandiri Kelautan yang dilaksanakan selama ini, (mis: program Pemberdayaan Ekonomi Masyarakat Pesisir, PEMP), belum mencapai sasaran bahkan ada yang gagal. Salah satu kegagalannya adalah lemahnya kinerja dari stakeholder yang terlibat dalam program dimaksud.

Tujuan penelitian ini adalah untuk mengetahui dan mengevaluasi kinerja masing-masing stakeholder program PNPM-Mandiri Kelautan Perikanan Kota Ternate.

\section{METODE}

Penelitian dilaksanakan Ternate, Provinsi Maluku Ûtara khususnya di Kecamatan Hiri (Kelurahan Faudu, Kelurahan Tafraka dan Kelurahan Tomajiko) yaitu-Okasji penerima bantuan PNPM-Mandir KP Tahun Anggaran 2009, Waktu penelitian dimulai bulan Januari hingga Mei 2012.

Metode penelitian yang digunakan adalah metode survey dan observasi, dimana informasi dari responden, yaitu stakeholder yang terlibat dalam program PNPM Mandiri Kelautan Perikanan T.A. 2009 dikumpulkan dengan menggunakan kuesioner dan wawancara. Adapun responden (stakeholder) dalam penelitian ini adalah : Kepala Dinas Kelautan dan Perikanan, Konsultan Pelaksana, Tim Pemberdayaan, Tenaga Pendamping, Kelompok Masyarakat penerima program.

Metode analisis yang digunakan untuk menjawab tujuan penelitian yaitu analisis deskriptif. Analisis ini untuk mengintrepretasi hasil tabulasi data pencapaian kinerja para pihak (stakeholder) terhadap pelaksanaan program PNPMMandiri KP tahun Anggaran 2009. Setiap pertanyaan di berikan skor 1 (satu) untuk jawaban "ya" dan skor 0 (nol) untuk jawaban "tidak/tidak tahu", kemudian dihitung persentase pencapaian hasil dari masing-masing stakeholder pelaksanaan program PNPMMandiri KP.

\section{HASIL DAN PEMBAHASAN}

Hasil pencapaian kinerja masingmasing stakeholder program PNPMMandiri Kelautan Perikanan kota 
Ternate, Tahun 2009 dapat dilihat pada Tabel 1.

Dari Tabel 1 menunjukkan bahwa kepala Dinas Kelautan dan Perikanan kota Ternate sebagai penanggung jawab operasional PNPM-Mandiri KP di Kota Ternate, capaian kinerjanya mencapai skor 90\%. Artinya Tupoksi yang dijalankan sangat baik. Walaupun kelompok masyarakat penerima bantuan menilai kepala dinas selaku kuasa pengguna anggaran tidak terbuka dalam program dimaksud. Sementara Tajerin et al. (2007) mengemukakan bahwa kebijakan perikanan perlu mendorong pengintegrasiaan dan keterbukaan secara vertikal.

Konsultan pelaksana berfungsi membantu dinas kelautan dan perikanan dari aspek teknis dan manajemen pelaksanaan program, capaian kinerjanya memperoleh skor sebesar $97 \%$. Ini menunjukkan bahwa kinerjanya sangat baik. Kegiatan konsultan pelaksana antara lain melakukan : 1) pelatihan peningkatan kapasitas aparatur, 2) pelatihan akses kredit mikro, dan 3) pelatihan peningkatan kapasitas masyarakat di bidang kelautan dan perikanan. Namun menurut kelompok masyarakat penerima bantuan program, satu pelatihan yaitu pelatihan akses kredit mikro tidak diketahui olen sebagian besar anggota kelompok karena informasi yang tidak sampai. Hal ini sangat mempengaruhi pada aspek penguatan kelembagaan, seperti yang dikemukakan oleh Numbery (2009) bahwa penguatan kelembagaan baik kelembagaan produksi, pemasaran dan permodalan sangatlah penting dalam usaha pemberdayaan masyarakat. Melalui

penguatan tersebut maka pelaku usaha memeliki posisi tawar yang lebih kuat.

- Tim pemberdayaan dibentuk guna memudahkan kordinasi antar instansi yang terkait program PNPM-Mandiri KP. Selain itu berfungsi sebagai perpanjangan tangan dari dinas perikanan dalam melakukan identifikasi, seleksi, verifikasi proposal dan sosialisasi program. Capaian kinerja Tim pemberdayaan skornya sebesar $91 \%$, artinya kinerjanya baik, dan dalam melaksanakan tugasnya sudah sesuai dengan petunjuk operasional program. Walaupun responden kelompok masyarakat penerima bantuan menilai tim pemberdayaan tidak melakukan pendampingan secara intens. Tim pemberdayaan hanya sekali turun bersama masyarakat, karena mereka sangat tergantung pada informasi yang disampaikan oleh tenaga pendamping. Menurut Kusnadi (2009), jika suatu kegiatan pemberdayaan hanya dilaksanakan sekali tanpa dilanjutkan dengan program pemberdayaan pada tahapan berikutnya atau tidak didukung dengan kegiatan pendampingan secara intens maka niscaya hasilnya kurang baik.

Berdasarkan hasil analisis kinerja, tenaga pendamping dalam program PNPM-Mandiri KP di Kota Ternate tahun Anggaran 2009, mencapai skor signifikan yaitu sebesar $92 \%$. Artinya tenaga pendamping sudah melaksanakan tugas dengan baik sesuai tupoksi. Namun, menurut responden kelompok masyarakat penerima bantuan, dalam pengembangan usaha, yaitu peningkatan produksi dan pemasaran, tenaga pendamping belum maksimal. Hal ini disebabkan tenaga pendamping tidak menetap dalam waktu lama bersama masyarakat, tempat tinggalnya di Kota Ternate yang berjarak 1,5 mil laut dari Kecamatan Hiri, di tempuh dengan perahu. Tenaga pendamping sangat terbatas yaitu hanya dua orang dan sangat mempengaruhi dalam penguatan pendampingan terhadap masyarakat, namun sering diabaikan oleh pengambil kebijakan, menurut Alhidayat in Tajerin et al. (2007), dalam mengembangkan usaha di pesisir secara optimal dan berkelanjutan maka perlu di analisis berbagai faktor pembatas sehingga mencapai titik equilibrium yang optimum.

Capaian kinerja kelompok masyarakat penerima bantuan program skornya sebesar $93 \%$, sangat baik. Namun ada permasalahan yang di hadapi kelompok masyarakat penerima bantuan program yaitu rendahnya kualitas SDM. Karena terbatasnya pengetahuan, 
mereka tidak memiliki kemampuan dalam melakukan perencanaan kegiatan serta penyusunan proposal, sehingga segala sesuatunya diserahkan kepada tenaga pendamping. Menurut Stefanus et al. (2007), bahwa pendekatan pemberdayaan masyarakat harus berpusat pada manusia (people-centered development), karena kemudian melandasi wawasan pengelolaan sumberdaya lokal (community-based management), yang merupakan mekanisme perencanaan people-centered development yang menekankan pada teknologi pembelajaran sosial (social learning) dan strategi perumusan program.

\section{KESIMPULAN}

Pelaksanaan Program Nasional Pemberdayaan Masyarakat (PNPM)Mandiri Kelautan Perikanan di Kota Ternate Tahun Anggaran 2009 di Kecamatan Hiri, secara umum sudah mencapai hasil yang baik. Hal ini dapat dilihat dari capaian kinerja pelaksana program (stakeholder) masing-masing yaitu, Kepala Dinas Perikanan 90\%; Konsultan pelaksana $97 \%$; Tim pemberdayaan $91 \%$; Tenaga pendamping $92 \%$ dan Kelompok Masyarakat 93\%

Dari hasil capaian kinerja di atas, khususnya pada kelompok masyarakat penerima bantuan program, perlu ditingkatkan kualitas sumberdaya manusianya, terutama dalam pemanfaatan dan pengelolaan sumberdaya pesisir dan laut di Kota Ternate, khususnya di Kecamatan Hiri. Pemerintah perlu mendorong peran serta lembaga permodalan dan pemasaran guna menunjang usaha masyarakat pesisir. Pengawasan dan pendampingan harus lebih intens terhadap kelompok masyarakat penerima bantuan program.

\section{DAFTAR PUSTAKA}

[BPS] Badan Pusat Statistik Kota Ternate. 2011. Ternate Dalam Angka. Ternate
Fauzi A. 2005. Kebijakan Perikanan dan Kelautan. PT Gramedia Pustaka Utama. Jakarta.

Masydzulhak. 2005, Pengelolaan Sumberdaya Pesisir di Kota Bengkulu (Tinjauan Bioekonomik Sumberdaya Perikanan), Jurnal Penelitian UNIB, Vol. XI, No 1.

Kusnadi. 2009. Keberdayaan Nelayan dan Dinamika Ekonomi Pesisir. Ar Ruzz Media. Yogyakarta

Numberi F. 2009, Evolusi Pembangunan Kelautan dan Perikanan Indonesia, Makalah Disampaikan pada Seminar Nasional Evolusi Kelautan Nusantara, Bogor

Stefanus S, Supriharyono, N.B. Azis. 2007. Pengelolaan Sumberdaya Pesisindan laut Melalui Pemberdayaan Kearifan Lokal Di Kabupaten Lembata Propinsi Nusa Tenggara Timur, Jurnal Pasir Laut, vol.69 2, No.2.

Tajerin, Y. Risna, Sastrawidjaja dan Asnawi. 2007. Keterkaitan Sektor Perikanan dalam Perekonomian Indonesia: Pendekatan Model InputOutput, Jurnal Bijak dan Riset Sosek KP. Vol.2 No.1 
Tabel 1. Capaian hasil kinerja pelaksana program PNPM Mandiri KP Kota Ternate tahun anggaran 2009.

\begin{tabular}{|c|c|c|}
\hline \multirow[b]{2}{*}{ Pelaksana } & \multicolumn{2}{|r|}{ Analisis Deskriptif } \\
\hline & $\begin{array}{l}\text { Pencapaian } \\
\text { Hasil }\end{array}$ & $\begin{array}{c}\text { Komentar Atas Pencapaian Kinerja } \\
\text { Pelaksana Program }\end{array}$ \\
\hline $\begin{array}{l}\text { Kepala Dinas } \\
\text { Perikanan }\end{array}$ & $90 \%$ & $\begin{array}{l}\text { Tugas kepala dinas sudah dijalankan } \\
\text { dengan baik, hanya saja menurut kelompok } \\
\text { masyarakat penerima bahwa beberapa hal } \\
\text { menyangkut kordinasi antar intansi dan } \\
\text { kuasa penguna anggaran tidak di ketahui } \\
\text { oleh masyarakat. }\end{array}$ \\
\hline $\begin{array}{l}\text { Konsultan } \\
\text { Pelaksana }\end{array}$ & $97 \%$ & $\begin{array}{l}\text { Kinerja Konsultan pelaksana sangat baik } \\
\text { menurut responden yang di wawancara, } \\
\text { namun menurut kelompok masyarakat } \\
\text { sebagian mereka tidak mendapatkan } \\
\text { informasi tentang satu pelatihan, yaitu } \\
\text { pelatihan akses kredit mikro, sehingga } \\
\text { mereka tidak mengikutinya }\end{array}$ \\
\hline $\begin{array}{l}\text { Tim } \\
\text { Pemberdayaan }\end{array}$ & $91 \%$ & $\begin{array}{l}\text { Kinerja tim pemberdayaan pada umumnya } \\
\text { baik, walaupun pengakuan dari responden } \\
\text { kelompok masyarakat, intensitas } \\
\text { pendampingan tim pemberdayaan hanya } \\
\text { sekali turun bersama masyarakat selama } \\
\text { program PNPM-Mandiri KP berjalan }\end{array}$ \\
\hline $\begin{array}{l}\text { Tenaga } \\
\text { Pendamping }\end{array}$ & & $\begin{array}{l}\text { 1. Padaumumnya tenaga pendamping sudah } \\
\text { menjalankan tugas dengan baik, walaupun } \\
\text { menurut reaponden kelompok masyarakat, } \\
\text { tim pendamping tidak menetap dalam waktu } \\
\text { yang lama dengan masyarakat karena } \\
\text { tempat tinggal tenaga pendamping di luar } \\
\text { lokasi program. } \\
\text { 2. Disisi lain jumlah Tenaga pendampinag } \\
\text { sangat terbatas yang tidak sebanding } \\
\text { dengan tugas. }\end{array}$ \\
\hline $\begin{array}{l}\text { mpok } \\
\text { arakat }\end{array}$ & $93 \%$ & $\begin{array}{l}\text { 1. Upaya partisipasi masyarakat dalam } \\
\text { program ini sangat baik, walupun menurut } \\
\text { mereka masih memiliki keterbatasan } \\
\text { pengetahuan dalam hal kemampuan } \\
\text { melakukan perencanaan kegiatan dan } \\
\text { pembuatan proposal. } \\
\text { 2. Ketergantungan terhadap tenaga } \\
\text { pendamping dan tim pemberdayaan }\end{array}$ \\
\hline
\end{tabular}

